Shahidul Islam, M. (2018). Dividend Practices in Listed Banks of Bangladesh. Copernican Journal of Finance \& Accounting, 7(2), 43-61. http://dx.doi.org/10.12775/CJFA.2018.008

\author{
Mohammad Shahidul Islam* \\ BGMEA University of Fashion and Technology
}

\title{
DIVIDEND PRACTICES \\ IN LISTED BANKS OF BANGLADESH ${ }^{* *}$
}

Keywords: dividend, EPS, signaling theory, MM model.

J E L Classification: G35.

Abstract: Corporate dividend behaviour is looked upon in many ways by the experts in the area of financial literature. To examine the dividend practices in banking sector in Bangladesh, it is taken secondary data and the views of dividend policy makers' covering the divergent aspects of dividend practices. The parametric test, non-parametric test and percentile are used for inferring the result. In the banking sector, the maximum payouts are in large size firm, earlier listed bank, low leveraged firm, high risk's firm, medium PE ratio's firm. The survey results reveal that the banks prefer both cash \& stock dividend most but majority shareholders prefer stock. The most of the companies follow stable payout with increasing trend in dividend payment but no satisfactory research is done to justify the investors' preference. The decision maker, investors and other stakeholders should follow these findings for taking decision.

Date of submission: August 7, 2018; date of acceptance: September 25, 2018.

* Contact information: shahidulislam28@yahoo.com, Department of Business Administration, BGMEA University of Fashion and Technology (BUFT), 105 Uttara Model Town, Sector 7, Dhaka-1230, Bangladesh, phone: 88 01758075844; ORCID ID: https:// orcid.org/0000-0002-5362-8622.

** The article was based on a doctoral dissertation titled "Dividend Practices in Corporate Sector of Bangladesh: A Study of the Companies Listed with Dhaka Stock Exchange" prepared by Mohammad Shahidul Islam, under the supervision of: Professor Dr. M. Farid Ahmed (Department of Finance, University of Dhaka) and Professor Dr. H.M. Mosarof Hossain (Department of Finance, University of Dhaka). 


\section{INTRODUCTION}

The financial decision is rotated around the dividend decision. So, to identify the dividend practices in the corporate sector in Bangladesh is vital objective of the study. The dividend pattern of listed companies and the management' practices of dividend policy are described for revealing the present scenario of dividend in the capital market of Bangladesh. This study shows the pattern of dividend payout with the different characteristics (category of company, age of the company, size, leverage, risk, PE etc). The dividend practices of the management are depicted with the questionnaire survey.

The corporations earn profits but they do not distribute all of it. The part of profit is ploughed back or held back as retained earnings. The part of the profit is distributed to the shareholders as dividend. The ratio of the actual distribution or dividend and the total distributable profits is called dividend payout ratio. How much of its profits should a corporation distribute? There are several considerations that are applied in answering this question. Hence, the companies have to frame work on a definitive policy of dividend payout ratio. Of course, no corporate management can afford to a fixed dividend payout ratio year after year. However, management has to decide its policy on its broad. The dividend policy is the policy used by a company to decide how much it will pay out to shareholders. From the share valuation model, the value of a share depends very much on the amount of dividend distributed to shareholders. The dividends are usually distributed in the form of cash or share. When a company distributes a cash dividend, it must have sufficient cash to do so. This creates a cash flow issue. This is a concern to the management as insufficient cash may mean the company is unable to distribute a dividend.

I have shown the details about the dividend scenarios in Bangladesh based on the secondary data (market data and company data) and survey from management.

\section{Previous Studies}

Out of the plethora of literatures available for the present area of study, the following literatures are reviewed having primary focus on finding out patterns in and issues influencing dividend payment. 
Lintner (1956) interviewed managers from 28 selected companies. He found a number of important stylized facts underlying the decision to pay dividends, which can be summarized as follows:

a) Firms have long-term target ratios of dividend payout;

b) Managers focus more on dividend changes than on absolute levels;

c) Dividend changes follow shifts in long run, sustainable levels of earnings rather than short-run changes in earnings;

d) Managers are reluctant to make dividend changes that might have to be reversed.

Prior to Miller and Modigliani (1961), there was a lack of the literature of a complete and reliable theoretical model of the effect of a firm's dividend policy on the current price of its shares. MM (1961) are the first to challenge the belief that a higher dividend payout translates into higher firm value. They concluded that only investment policy rather than dividend policy determines firm value in an ideal economy. Dividend policy merely establishes a tradeoff between dividends at one date and dividends at another date because both the corporations and the individual investors can create any cash inflow stream by making homemade dividends. It means that any desired stream of payments can be replicated by appropriate purchases and sales of equity. Thus, investors will not pay a premium for any particular dividend policy. The net payout can be considered as the difference between the wealth generated from preceding investment and the amount of capital required by the future opportunity of growth, and is simply a residual.

Investors prefer cash in the hand rather than a future promise of capital gains due to lower risk (Gordon, 1962, 1963; Walter, 1963). The corporate finance literature offers a variety of explanations for dividends and the puzzle that they present. In essence, three fundamental positions can be found in the literature with respect to dividends. The first of these, the so-called 'bird-inthe hand' hypothesis (Gordon \& Shapiro, 1956) posits that dividends can increase firm value by reducing the risk perceived by investor in corporate cash flows. It holds that, other things equal, if two firms, $A$ and $B$, are identical in all respects save that firm A pays a dividend with expectations of future dividend growth, then A will have a higher share price.

Signaling models were first developed in the late 1970s and early 1980s. Akerlof (1970) explained the cost of asymmetry information by applying the market for used CAR as a pooling equilibrium in the absence of signaling activities. Next, using a scenario in the employment market, Spence $(1973,1974)$ carries 
out a formal partial equilibrium analysis of market signaling. Spence's (1974) signaling model has been extensively used by some researchers to study financial models of signaling.

Managers give investors what they currently want. That is, they cater to investor demand by paying dividends when investors put a stock price premium on payers, and by not paying when investors prefer non payers (Baker \& Wurgler, 2004a, 2004b). Compared with the traditional rationality assumptions, behavioral corporate finance is potentially more realistic, in that it emphasizes that both investor and managerial behaviors are less than fully rational. In practice, corporate payout policy can be influenced by the irrational actions of managers and/or investors (Barberis \& Thaler, 2003; Baker, Saadi, Dutta \& Gandhi, 2007).

Dividends help to reduce the agency costs associated with the separation of ownership and control (Jensen \& Meckling, 1976; Rozeff, 1982; Easterbrook, 1984; Jensen, 1986). Miller and Modigliani (1961) proposed that, in frictionless environment, the choice between cash distribution and retention will not affect substantially the firm value, and only investment decisions matter. However, in the real world the conflicts of interests among managers, shareholders and debt holders may hurt the firm value. Dividend policy will be relevant if it affects substantially these conflicts of interest. Traditional residual theory of dividends suggests that dividends distributed are the residual funds after making investment decisions

Dividend policy tends to follow a firm's life cycle that a firm begins paying dividends when its growth rate and profitability are expected to decline in the future (Mueller, 1972; Fama \& French, 2001; DeAngelo, DeAngelo \& Stulz, 2006). Firms have their own life cycle. Premised on Knight (1921) and Schumpeter (1934), Mueller (1972) proposed a formal life cycle theory. The start-up stage can be difficult for a fresh firm because of the existing market threshold. The limited initial resources must be invested into product development, marketing and organization. After the startup stage, the firm will reach a high-growth stage during which it expands customers and exploits the market potential. Firms will eventually reach a point at which they progress from a high growth period to a so called 'maturity period'. With increasing market competition, profitable investment opportunities become absent and the growth rate declines.

Dhameja (1978) showed that there is no statistically significant relationship between dividend payout and industry classification, size. The Growth is found to be significantly and inversely related to dividend payout. As regards 
dividend rates controlling for bonus and rights issues, it is related directly and significantly to industry classification and growth, and mildly related to size.

Bhat and Pandey (1994) showed that payment of dividend depends largely upon current and expected earnings as well as on the pattern of past dividends, and liquidity is not a matter of consideration in dividend policy.

Collins, Saxena and Wansley (1996) studied the role of insiders in determination of dividend policy of a firm. Study results indicate that payout ratio is negatively related to firm's past and future expected growth rate of earnings, its level of systematic risk and its insider holdings. They also found that regulatory status plays more important role in the determination of strength of association between insider holding and payout ratio in the case of utilities than in the case of financial firms.

Gupta (1999) showed that regular dividend payments have been the feature in almost all the selected companies though there have been a gradual decline in the proportion of dividend payments to the available earnings for distribution. He also found that dividend rates are more inflated in comparison to the real effective rates of dividend as represented by dividend yield. In the matter of stability in dividend payments, he found high stability in terms of dividend yields but not so much in terms of dividend rates and dividend payouts.

La Porta, Lopez-de-Silanes, Shliefer and Vishny (2000) hold that firms in countries with better investor protection make higher dividend payouts than do the firms in countries with lower investor protection. Moreover, in countries with more legal protection, high growth firms have lower payout ratios. This finding supports the outcome agency model where investors use their legal power to force dividends when growth prospects are low. Thus, their findings indicate that without enforcement of management there is not a strong incentive to 'convey its quality' through payout policy. There is also no evidence that in countries with low investor protection, management will voluntarily commit itself to payout higher dividends and to be monitored more frequently by the market.

Again, Gugler (2003) observed that state-controlled firms are characterized by dividend smoothening, very high payout and strong reluctance to cut dividends while family-controlled firms are not subject to dividend smoothening, have a low payout and are least reluctant to cut dividends. According to him, this finding applies more to firms having good growth prospects (positive R\&D spending). But, in case of firms with low investment opportunities (no R\&D spending), target payout ratio tends to be much higher irrespective of who controls the corporation (state control or family control). 
DeAngelo, DeAngelo and Skinner (2004) observed that during the period of their study (1978-2000) nominal dividends paid by the companies in US increased manifold, even real dividends doubled during this period. This aggregate dividend increase is even in the face of radical decline in the number of dividend-payers. They found that both dividend and earnings concentration have increased substantially from the already high level.

Brav, Graham, Harvey and Michaely (2005) observed that dividend level is a priority at par with the investment decisions, and increase in dividend is considered only after investment and liquidity needs are met. They opined that managers express strong desire to avoid dividend cuts except in extraordinary circumstances. They also pointed out that sustainable increase in earnings and demand by institutional investors are the two root causes for the non-payers to initiate dividend payment. They found little support for signaling theories. They also found no evidence that managers use payout policy to attract particular investment clientele. Their survey also suggests that taxes are not the first-order important factor in the determination of payout policy but they are important at the margin of some firms (a very small proportion of dividend initiating firms).

Oza (2005) identified 'current year's earnings', 'patterns of past dividends', 'availability of cash' and 'expected future earnings' as major determinants of dividend policy. While, factors like 'capital expenditure requirements', 'impact on share prices', 'achieving target payouts', 'restrictions imposed by lenders', 'bonus issue by the companies' and 'industry practices' are found to have less significant role in the matter of deciding on dividend payments.

Huda and Farah (2011) explored the determinants of the dividend policy of firms in the banking industry of Bangladesh. Dividend decision of a bank basically depends on its size, profitability, liquidity and retained earnings. The study is an attempt to find out the key dividend determinant variables and their impact over cash, stock and total payout ratio. Statistical techniques of simple and multiple regressions have been used to explore the relationships between variables. The investigation results show the predictor variables have a significant relationship with stock payout and an apparent relationship with cash payout. Amongst all the independent variables, Net Income turns out to be most influential indicator in elucidating dividend payouts.

Zaman (2013) studied to determine factors that have statistically significant impacts on the dividend policy of banks with multiple regression analysis and it is seen that bank profitability, growth, and size are not significant in ex- 
plaining bank dividend policy in 2006. However, their role in explaining dividend strengthens with time till 2010.

Ahmed and Mukit (2014) identified the impact of various factors determining the firm's dividend paying behavior in the capital market of Bangladesh. They found that in Bangladesh profitability, corporate tax and market to book value ratios are the significant determinants of dividend payout ratio and operating cash flow per share, current ratio and debt to equity ratio are the insignificant determinants of dividend payout ratio.

\section{RESEARCH Methodology}

\section{Sample}

I have taken banks from financial sectors, which are enlisted before 2010 in DSE as population. From the population (30), it is taken 22 companies as sample through sample size determination techniques.

$$
\begin{aligned}
& \mathrm{N} \\
& \left(n=1+N(e)^{2}\right. \\
& \mathrm{n}=\text { sample size }, \mathrm{N}=\text { population size }, \mathrm{e}=\text { level of precision) }
\end{aligned}
$$

The study period is 20 years from 1994 to 2013. This research is an analytical research based on secondary data. The secondary data is taken from following sources: published annual reports of sample banks, monthly review of Dhaka stock exchange and website of DSE. The stratified random sampling procedure is followed for data collection.

\section{Primary data:}

\section{Survey Instruments}

The present research is based on an empirical study of 22 listed banks from the DSE with the objective of identifying the dividend policies practices. The data has been collected through the primary mode using a structured questionnaire 
containing 8 statements based on 5 point likert scale where Strongly agree $=2$, Agree $=1$, Indifferent $=0$, Disagree $=-1$, Strongly disagree $=-2$. The respondents are asked to indicate the level of agreement on issues for their firm's dividend policy. There are 8 multiple choice questions are also given to respondents. The questionnaire has been prepared after reviewing the prior studies on dividend practices by decision maker. The survey follows the literature of Baker and Powell (2000), Brav et al. (2005), Edelman (1983) etc.

I mailed the survey instruments to the chief financial officer (CFO) and Managing director, Chairman, Board of directors of each firm in September 2013. The mailing included a cover letter and a stamped return envelope. The cover letter assured recipients that their answers would be confidential and released only in summary form. But I did not find satisfactory response. So, later, I went personally to the respondents of each firm and finally collected 108 questionnaires as a sample.

\section{Parametric and on parametric Test}

I have used one-sample t-test to determine whether the mean response for each of the 8 factors involving dividend policy differs significantly from 0 (Indifferent). This study follows the test of Baker and Powell (2000), Brav et al. (2005), etc. The non -parametric test (Chi-square test) is also done which is similar testing tools of Edelman and Farrelly (1983).

\section{Secondary data:}

The study is based on secondary data obtained from published annual reports of sample firms, monthly review of Dhaka stock exchange and website of DSE. It is taken 22 banks from banking sectors as sample. The sample period is 20 years from 1994 to 2013 for study. The data are analyzed with descriptive way of dividend practices in Bangladesh. 
Analysis and Interpretations: Banking Sector

1. Dividend Performance: An analytical study on banking Sector

1.1. Sectoral performance of dividend and dividend related issues

Table 1. Dividend performance

\begin{tabular}{|c|c|c|c|c|c|}
\hline \hline Sectors & DPR & DPS & EPS & DY & MPS \\
\hline \hline Bank & 18.52919 & 23.87359 & 81.49525 & 1.889658 & 1221.601 \\
\hline \hline
\end{tabular}

S o u r c e : author's calculation.

From the table 1, it is observed that the DPR, DPS, EPS, DY, MPS are 18.52, $23.87,81.49,1.88,1221$ respectively. The DPR is lower than other manufacturing sector but DPS is more than other sector. It indicates that the banking sector provide more stock dividend than the manufacturing sectors. The EPS and MPS are much higher than some manufacturing sectors.

\subsection{Dividend payment of different categories}

Table 2. Dividend performance of different categories

\begin{tabular}{|c|c|c|c|c|c|}
\hline \hline Category & DPR & DPS & EPS & DY & MPS \\
\hline \hline $\mathrm{A}$ & 18.52919 & 23.87359 & 81.49525 & 1.889658 & 1221.601 \\
\hline \hline
\end{tabular}

S o u r c e : author's calculation.

It is observed from the table 2 that the most of the banks pay the dividend regularly. So, the sample belongs to A category only. 


\subsection{Dividend nature of different size of the banks}

Table 3. Dividend performance of different size of the banks

\begin{tabular}{|l|l|l|l|l|c|}
\hline \hline \multicolumn{1}{|c|}{ Size } & DPR & DPS & EPS & DY & MPS \\
\hline \hline Large Size & 27.4462 & 21.7159 & 31.2467 & 1.97577 & 2120.39 \\
\hline Medium Size & 11.96 & 26.84 & 117.6 & 1.801 & 567.8 \\
\hline Small Size & 14.52721 & 17.24615 & 109.1067 & 1.990385 & 773.1755 \\
\hline \hline
\end{tabular}

S o u r c e : author's calculation.

In the table 3, the DPR of large size, medium size and small size are the $27.44,11.96$, and 14.52 percent respectively which indicates that large banks provide more dividends. The MPS of large banks is more than the medium and small banks. But the DPS and EPS of Medium size banks have more than the other two groups.

\subsection{Dividend payment nature of different age of the banks}

Table 4. Dividend performance of different age of the banks

\begin{tabular}{|c|c|c|c|c|c|}
\hline \hline Year & DPR & DPS & EPS & DY & MPS \\
\hline \hline $1980-1990$ & 14.25475 & 23.29433 & 39.07967 & 4.363083 & 497.5725 \\
\hline $1990-2000$ & 21.64 & 22.25 & 35.64 & 2.911 & 378.3 \\
\hline $2000-2005$ & 17.84 & 27.38 & 132.2 & 1.781 & 644 \\
\hline $2005-2010$ & 20.9 & 18.28 & 25.11 & 0.511 & 2924 \\
\hline \hline
\end{tabular}

S o u r c e : author's calculation.

It is observed from the table 4 that the DPR of the later listed companies is more than the earlier listed companies (i.e. 2005-10: 20.9\%, 2000-05: 17.84\%, 1990-00: 21.64\%, 1980-90: 14.25\%). 


\subsection{Dividend and leverage}

Table 5. Leverage and Dividend performance

\begin{tabular}{|l|c|c|c|c|c|}
\hline \hline \multicolumn{1}{|c|}{ Leverage } & DPR & DPS & EPS & DY & MPS \\
\hline \hline High leveraged firm & 11.04 & 23.7 & 127.4 & 1.431 & 456.8 \\
\hline Medium leveraged firm & 18.1 & 21.96 & 31.4 & 1.71 & 2955 \\
\hline Low leveraged firm & 28.52335 & 25.73311 & 65.42094 & 2.633198 & 718.8738 \\
\hline \hline
\end{tabular}

S o u r c e : author's calculation.

In the table 5 , the DPR, DPS, EPS, DY, MPS of low leveraged firm are 28.52 percent, $25.73,65.42,2.63,718.87$ respectively and these are higher than the high and medium leveraged firm. It indicates that the low leveraged bank performed better in dividend and dividend related issues.

\subsection{Dividend and Risk}

Table 6. Risk and Dividend performance of different banks

\begin{tabular}{|l|c|c|c|c|c|}
\hline \hline \multicolumn{1}{|c|}{ Risk } & DPR & DPS & EPS & DY & MPS \\
\hline \hline High risk firm & 23.68 & 23.45 & 50.7 & 1.38 & 709.1 \\
\hline Medium risk firm & 16.53 & 25.01 & 132.3 & 2.546 & 448.2 \\
\hline Low risk firm & 7.380725 & 21.85682 & 31.66715 & 1.618924 & 446.5665 \\
\hline \hline
\end{tabular}

S o u r c e : author's calculation.

The DPR of high risky firms is more than the medium and low risky firms but the DPS, EPS, DY of medium risky firms are 25.01, 132.3, and 2.54 respectively which are more than the other two groups (table 6). 


\subsection{Dividend and Ownership}

Table 7. Ownership and Dividend performance of different banks

\begin{tabular}{|l|c|c|c|c|c|}
\hline \hline \multicolumn{1}{|c|}{ Majority Shareholdings } & DPR & DPS & EPS & DY & MPS \\
\hline \hline Sponsor (50\% and above) & 26.63 & 23.78 & 55.39 & 2.161 & 772.6 \\
\hline Individual (40\% and above) & 12.93 & 23.23 & 34.03 & 1.704 & 415.2 \\
\hline \hline
\end{tabular}

S o u r c e : author's calculation.

It is seen from the table 7 that those banks' majority shareholders who are sponsors have higher DPR (26.63\%), DPS (23.78), EPS (55.39), DY (2.16), and MPS (772.6).

\subsection{Dividend and $P E$}

Table 8. PE and Dividend performance of different banks

\begin{tabular}{|l|c|c|c|c|c|}
\hline \hline \multicolumn{1}{|c|}{ Class } & DPR & DPS & EPS & DY & MPS \\
\hline \hline $20+$ & 4.123 & 19.02 & 26.44 & 1.294 & 444.1 \\
\hline $15-20$ & 26.82 & 25.23 & 67.5 & 1.169 & 3371 \\
\hline $10-15$ & 16.21 & 23.3 & 110.5 & 2.04 & 410.8 \\
\hline $5-10$ & 28.02254 & 30.25 & 46.78536 & 4.118571 & 398.1518 \\
\hline \hline
\end{tabular}

S o u r c e : author's calculation.

In the table 8, the class of PE ratio between ' $5-10$ ' is the best class in respect of dividend related variables (DPR: 28.02, DPS: 30.25, DY: 4.11). The extremely higher class (20+) indicates the worst position of dividend related performance (DPR: 4.12, DPS: 19.02, DY: 1.29). 


\subsection{Dividend and its payment trend}

Table 9. Dividend and its payment trend

\begin{tabular}{|c|c|c|c|c|c|}
\hline \hline Pattern & DPR & DPS & EPS & DY & MPS \\
\hline \hline Regular & 18.52919 & 23.87359 & 81.49525 & 1.889658 & 1221.601 \\
\hline
\end{tabular}

S o u r c e : author's calculation.

It is found that the majority banks pay the dividend regularly. The DPR of banking sector is lower comparison to other sectors.

\section{Dividend Practices: Survey on banking sector}

Table 10. Survey results of dividend practices

\begin{tabular}{|c|c|c|}
\hline \multirow{5}{*}{$\begin{array}{l}\text { Shareholders' Preference for forms } \\
\text { of dividend }\end{array}$} & Issues & Percentage of Preference \\
\hline & Cash dividend & 45.45 \\
\hline & Stock dividend & 54.55 \\
\hline & Right Issue & 0.00 \\
\hline & Stock repurchase & 0.00 \\
\hline \multirow{5}{*}{$\begin{array}{l}\text { Companies' Preference for forms of } \\
\text { dividend }\end{array}$} & Cash dividend & 5.52 \\
\hline & Stock dividend & 22.73 \\
\hline & Cash and Stock & 67.21 \\
\hline & Stock repurchase & 0.00 \\
\hline & No preference & 4.54 \\
\hline \multirow{5}{*}{$\begin{array}{l}\text { Reason for companies' preference in } \\
\text { choosing form of dividend }\end{array}$} & Easy to implement & 4.54 \\
\hline & More flexible & 9.09 \\
\hline & Maintaining consistency & 45.50 \\
\hline & Majority shareholders' expectation & 27.30 \\
\hline & other & 13.60 \\
\hline
\end{tabular}


Table 10. Survey results of dividend practices

\begin{tabular}{|c|c|c|}
\hline \multirow[t]{3}{*}{ Dividend payment patterns } & Regular & 81.8 \\
\hline & Irregular & 13.6 \\
\hline & No dividend payment & 4.55 \\
\hline \multirow[t]{4}{*}{ Dividend payment policies } & Stable payout ratio & 54.5 \\
\hline & Constant DPS & 18.18 \\
\hline & Regular plus extra dividend & 4.55 \\
\hline & Residual dividend policy & 22.7 \\
\hline \multirow[t]{3}{*}{ Dividend payment trend } & Increasing trend & 50.00 \\
\hline & Decreasing trend & 13.6 \\
\hline & Unchanged & 36.4 \\
\hline \multirow{5}{*}{$\begin{array}{l}\text { Manager's target for dividend } \\
\text { decision }\end{array}$} & Amount of dividend & 13.6 \\
\hline & Growth in dividend & 22.73 \\
\hline & Dividend yield & 22.73 \\
\hline & Dividend payout ratio & 22.73 \\
\hline & No target at all & 18.2 \\
\hline \multirow[t]{2}{*}{ Research for dividend preference } & Yes & 22.73 \\
\hline & No & 77.3 \\
\hline
\end{tabular}

S o u r c e : author's calculation.

From the above table 10, the managers think that the maximum shareholders prefer stock dividend (54.55\%). The 45.45 percent shareholders expect cash dividend. The companies prefer 'cash and stock' dividend to distribute among the shareholders. The 67.20 percent companies prefer to pay both 'cash and stock' dividend but 5.52 percent companies prefer only cash dividend. The 22.73 percent companies prefer stock dividend. The companies prefer earlier form of dividend payment because of majority shareholders' expectation (27.3\%). Other reasons for choosing the form of dividend is maintain consistency $(45.5 \%)$.

The maximum companies pay the dividend regularly (81.8\%) and $13.6 \%$ company pay the dividend irregularly. But only 4.55 percent companies did not pay the dividend at all. The 54.50 percent companies take the stable dividend payout policy. The companies' other policies are constant dividend per share 
(18.18\%), regular plus extra dividend (4.55\%), and residual dividend policy (22.7\%).

The dividend increasing trend, decreasing trend, unchanged trend are 50\%, $13.6 \%, 36.4 \%$ companies respectively. The most of the companies target the growth in dividend $(22.73 \%)$ and dividend payout ratio $(22.73 \%)$ and remarkable number of companies has no target at all (18.2\%). Only $22.73 \%$ companies' conduct research on the dividend preference of the shareholders and 77.3 percent companies don't conduct any research on shareholders' preference.

\section{Company's views about the dividend policies of banking sector}

Table 11. Company's view on the dividend policies

\begin{tabular}{|c|c|c|c|c|c|c|c|c|c|c|c|c|}
\hline \multirow{2}{*}{$\begin{array}{l}\frac{1}{\Xi} \\
\text { है } \\
\text { है } \\
z\end{array}$} & \multirow[b]{2}{*}{ Statements } & \multicolumn{5}{|c|}{ Level of Agreement (\%) } & \multirow[b]{2}{*}{ Mean } & \multirow[b]{2}{*}{ Rank } & \multirow[b]{2}{*}{ t-test } & \multirow[b]{2}{*}{$\begin{array}{l}\text { Sig. } \\
\text { (2-ta- } \\
\text { iled) }\end{array}$} & \multirow[b]{2}{*}{$\begin{array}{c}\text { Chi } \\
\text { square } \\
\text { value }\end{array}$} & \multirow[b]{2}{*}{$\begin{array}{l}\text { Asymp. } \\
\text { Sig. }\end{array}$} \\
\hline & & $\begin{array}{l}\text { Stron- } \\
\text { gly } \\
\text { Agree }\end{array}$ & Agree & $\begin{array}{c}\text { Indiffe- } \\
\text { rent }\end{array}$ & $\begin{array}{l}\text { Disa- } \\
\text { gree }\end{array}$ & $\begin{array}{l}\text { ly } \\
\text { Dis- } \\
\text { agree }\end{array}$ & & & & & & \\
\hline 1 & $\begin{array}{l}\text { We try to avoid redu- } \\
\text { cing dividends per sha- } \\
\text { re, because there are } \\
\text { negative consequences } \\
\text { of reducing dividends }\end{array}$ & 31.82 & 31.82 & 13.64 & 9.09 & 13.64 & .590 & 5 & 1.97 & .061 & 5.27 & .26 \\
\hline 2 & $\begin{array}{l}\text { Rather than reducing } \\
\text { dividends, we raise } \\
\text { new funds to underta- } \\
\text { ke a profitable project }\end{array}$ & 4.54 & 31.82 & 22.73 & 22.73 & 18.18 & -.181 & 7 & -.69 & .492 & 4.36 & .35 \\
\hline 3 & $\begin{array}{l}\text { We make dividend } \\
\text { decisions after taking } \\
\text { investment plans }\end{array}$ & 22.73 & 36.36 & 18.18 & 18.18 & 4.54 & .545 & 6 & 2.16 & .042 & 5.72 & .22 \\
\hline 4 & $\begin{array}{l}\text { We develop dividend } \\
\text { policy for maximizing } \\
\text { the company's market } \\
\text { value }\end{array}$ & 54.55 & 36.36 & 9.09 & 0 & 0 & 1.45 & 1 & 10.16 & .000 & 8.35 & .032 \\
\hline 5 & $\begin{array}{l}\text { We change dividends } \\
\text { based on sustainable } \\
\text { shift in earnings }\end{array}$ & 45.45 & 31.82 & 18.18 & 4.54 & 0 & 1.18 & 4 & 6.11 & .000 & 8.18 & .042 \\
\hline 6 & $\begin{array}{l}\text { We try to maintain } \\
\text { a smooth dividend } \\
\text { stream from year to } \\
\text { year }\end{array}$ & 54.55 & 31.82 & 13.64 & 0 & 0 & 1.40 & 2 & 9.00 & .000 & 7.23 & .05 \\
\hline
\end{tabular}


Table 11. Company's view on the dividend policies

\begin{tabular}{|c|c|c|c|c|c|c|c|c|c|c|c|c|}
\hline \multirow{2}{*}{ 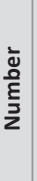 } & \multirow[b]{2}{*}{ Statements } & \multicolumn{5}{|c|}{ Level of Agreement (\%) } & \multirow[b]{2}{*}{ Mean } & \multirow[b]{2}{*}{ Rank } & \multirow[b]{2}{*}{ t-test } & \multirow[b]{2}{*}{$\begin{array}{l}\text { Sig. } \\
\text { (2-ta- } \\
\text { iled) }\end{array}$} & \multirow[b]{2}{*}{$\begin{array}{c}\text { Chi } \\
\text { square } \\
\text { value }\end{array}$} & \multirow[b]{2}{*}{$\begin{array}{c}\text { Asymp. } \\
\text { Sig. }\end{array}$} \\
\hline & & $\begin{array}{l}\text { Stron- } \\
\text { gly } \\
\text { Agree }\end{array}$ & Agree & $\begin{array}{c}\text { Indiffe- } \\
\text { rent }\end{array}$ & $\begin{array}{l}\text { Disa- } \\
\text { gree }\end{array}$ & $\begin{array}{c}\text { ly } \\
\text { Dis- } \\
\text { agree }\end{array}$ & & & & & & \\
\hline 7 & $\begin{array}{l}\text { We pay dividends for } \\
\text { showing better per- } \\
\text { formance compare to } \\
\text { competitors }\end{array}$ & 9.09 & 2273 & 9.09 & 40.91 & 18.18 & -.363 & 8 & -1.319 & .201 & 6.54 & .11 \\
\hline 8 & $\begin{array}{l}\text { We make dividend } \\
\text { policy based on ma- } \\
\text { jority shareholders' } \\
\text { expectation }\end{array}$ & 45.55 & 36.36 & 13.64 & 0 & 4.54 & 1.18 & 3 & 5.508 & .000 & 9.63 & .022 \\
\hline
\end{tabular}

S o u r c e : author's calculation.

From the table 11, the statements 4, 5, 6, 8 are significant in both test and chi square test. The statement 4 ('we develop dividend policy for maximizing the company's market value) has highest mean value (1.45) and got 87.27 percent opinion of respondents at 'agree and strongly agree' level. This statement is statistically significant with t test and chi-square test. It indicates that the companies set dividend policy with aims to maximize the market value of share. The 86.37 percent companies have 'agree and strongly agree' opinion on the statement 6 ('we try to maintain a smooth dividend stream from year to year') which is statistically significant with t test and chi-square test. So, the companies maintain the consistency in paying the dividend. The 81.91 percent companies have 'agree and strongly agree' have opinion on the statement 8 ('we make dividend policy based on majority shareholders' expectation') which is statistically significant with t test and chi-square test. So, the companies take their dividend decision by considering the majority shareholders' expectation.

The statements 1, 2, 7 are not significant in both t- test and chi square test and statement 3 is insignificant in chi square test. The statement 7 ('we pay dividends for showing better performance compare to competitors') is not statistically significant which indicates that the companies do not pay dividend for showing better performance compares to competitors. 


\section{RECOMMENDATIONS}

The study has found the corporate dividend policy practices related findings such as regulatory problems, policy related problems, application of model related issues etc. Accordingly, the study suggested the following measures:

- The companies should follow continuous dividend policy practices with a view to boosting investor morale as well as keeping stock market as safe harbor for investment and financing sector.

- The main determinants of dividend decisions are earnings and liquidity. So, company has to consider significant earnings and liquidity position for paying smooth dividend.

- The dividend announcement has the signaling effect on the market price of share. The corporate dividend decision and investors' investing decision should consider this finding.

- The corporate firms should follow non identical dividend policies depending on own characteristics, financing, and investing opportunities and expectation of market participants.

- The companies should make corporate dividend policies and undertake corporate dividend decision in line with the objective of maximizing share holders' wealth.

- The earlier reactions of dividend announcements indicate the leakage of information in the market. So, there should be taken the regulatory measures for preventing it.

\section{U11 ConCLUSION}

This study depicts the picture of dividend performance in the capital market of Bangladesh. In the banking sector, the maximum payouts are in large size firm, earlier listed bank, low leveraged firm, high risk's firm, medium PE ratio's firm. The survey results reveal that the banks prefer both cash \& stock dividend most but majority shareholders prefer stock. The most of the companies follow stable payout with increasing trend in dividend payment but no satisfactory research is done to justify the investors' preference. The decision maker, investors and other stakeholders should follow these findings for taking decision. The future researchers can cover the other financial sector for their study. 


\section{REFERENCES}

Akerlof G.A. (1970). The market for lemons: quality uncertainty and the market mechanism, Quarterly Journal of Economics, 84(3), 489-500.

Ahmed, M., \& Mukit, M.(2014). Determinants of Dividend Payout Ratio: Evidence from Dhaka Stock Exchange. ASA University Review, 2014, 8(2), 281-289.

Baker, H.K., \& Powell, G.E. (2000). Determinants of corporate dividend policy: a survey of NYSE firms. Financial Practice and education, 10(1), 29-40.

Baker, M., \& Wurgler, J. (2004a). A catering theory of dividends. Journal of Finance, 59(3), 1125-1165.

Baker, M., \& Wurgler, J. (2004b). Appearing and Disappearing Dividends: The Link to Catering Incentives. Journal of Financial Economics, 73(2), 271-288.

Baker, H.K., Saadi, S., Dutta, S., \& Gandhi, D. (2007). The perception of dividends by Canadian managers: New survey evidence. International Journal of Managerial Finance, 3(1), 70-91.

Barberis, N., \& Thaler, R. (2003). A survey of behavioral finance. In G.M. Constantinides, M. Harris, R.M. Stulz (Eds.). Handbook of the economics of finance. Amsterdam: North-Holland.

Bhat, R., \& Pandey, I.M. (1994). Dividend Decision: A Study of Managers' Perceptions. Decision, 21 (1 \& 2), 67-86.

Brav, A., Graham, J., Harvey, C.R., \& Michaely, R. (2005) Payout Policy in the 21st Century. Journal of Financial Economics, 77(3), 483-528.

Collins, M. C., Saxena, A. K. and Wansley, J. W. (1996). The role of insiders and dividend policy: a comparison of regulated and unregulated firms. Journal of Finance and Strategic Decisions, 9(2), 1-9.

DeAngelo, H., DeAngelo, L., \& Skinner, D.J. (2004). Are Dividends Disappearing? Dividend Concentration and the Consolidation of Earnings. Journal of Financial Economics. 72(3), 425-456.

Dhemeja, N.L. (1976). Corporate Dividend Behaviour with Special Emphasis on Growth and Controlled Companies. Unpublished Doctoral Dissertation, IIM, Ahmedabad, India.

Easterbrook, F.H. (1984). Two agency-cost explanations of dividends. American Economic Review, 74(4), 650-659.

Fama, E., \& French, K. (2001). Disappearing dividends: Changing firm characteristics or lower propensity to pay? Journal of Financial Economics, 60(1), 3-43.

Farrelly, G.E., Baker, K.H., \& Edelman, R.B. (1986), Corporate Dividends: Views of the Policy Makers. Akron Business and Economic Review, 17(4), 62-74.

Gordon, M.J. (1963). Optimal Investment and Financing Policy. Journal of Finance, 18(2), 264-272.

Gordon M.J. (1962). The savings, investment and valuation of a corporation, Review of Economics and Statistics, 44, 37-51. 
Gugler, K. (2003). Corporate Governance, Dividend Payout Policy, and the Interrelation between Dividends, R\&D, and Capital Investment, Journal of Banking and Finance, 27(7), 1297-1321.

Gordon, M.J., \& Shapiro, E. (1956). Capital equipment analysis: the required rate of profit, Management Science, 3(1), 102-110.

Gupta, A. (1999). Dividend Policy in MNC-owned Indian Subsidiaries A Post-1994 Study with Reference to Selected Companies. Indian Accounting Review, 3(1).

Huda, F., \& Farah, T. (2011). Determinants of dividend decision: A focus on banking sector in Bangladesh. International Research Journal of Finance and Economics, 77(1).

Jensen, M., \& Meckling, W. (1976). Theory Managerial Behaviours, Agency Cost and Ownership Structure. Journal of Financial Economics, 3, 305-306.

Jensen, M. (1986). Agency costs of free cash flow, corporate finance, and takeovers. American Economic Review, 76, 323-329.

Knight, F.H. (1921). Risk, Uncertainty, and Profit. New York: Hart, Schaffner, and Mary.

Lintner, J. (1956). Distribution of Incomes of Corporations among Dividends, Retained Earnings, and Taxes. American Economic Review, 46, 97-113.

La Porta, R., Lopez-De-Silanes, F., Shleifer, A., \& Vishny, R. (2000). Agency problems and dividend policies around the world. Journal of Finance, 55, 1-33.

Miller, M., \& Modigliani, F. (1961). Dividend Policy, Growth and Valuation of Shares. Journal of Business, 34, 411-413.

Mueller, D.C. (1972). A Life Cycle Theory of the Firm, Journal of Industrial Economics, 20(3), 199-219.

Oza, H.S. (2004). Dividend Decision: A Managerial Approach [A Study of Selected Enterprises].Executive Chartered Secretary, November, 40-46.

Rozeff, M.S. (1982). Growth, Beta and Agency Costs as Determinants of Dividend Payout Ratios. Journal of Financial Research, 5(3), 249-259.

Spence, M. (1973). Job Marketing Signaling. The Quarterly Journal of Economics , 87(3), 355-374.

Spence M., (1974). Competitive and optimal responses to signals: an analysis of efficiency and distribution, Journal of Economic Theory, 7(3), 296-333.

Schumpeter, J.A. (1934). The Theory of Economic Development. Cambridge: Harvard University Press.

Walter, J.E. (1963). Dividend policy: its influence on the value of the enterprise. Journal of Finance, 18(2), 270-291.

Zaman, S. (2013). Determinants of Dividend Policy of A Private Commercial Bank in Bangladesh: Which is The Strongest, Profitability, Growth or Size? In M.H. Bhuiyan (Ed.). Proceedings of 9th Asian Business Research Conference. Dhaka: BIAM Foundation. 
